\title{
Gezegenlerin hareketinden mûsikî nağmelerine
}

\section{Yalçın Çetinkaya}

İTÜ Türk Mûsikîsi Devlet Konservatuvarı, İstanbul, Türkiye

yalcincetinkaya60@gmail.com

\section{Özet}

Mûsikîyi kâinat ile izah etmek, kadîm bir gelenektir. İslâm düşünce dünyasında da mûsikî, kozmik sembollerle ve varlıklarla açıklanır ancak bu açıklamalar tamamen İslâm düşünürlerinin geliştirdikleri orijinal bir açılamadır, bu kadîm bir mûsikî öğretisidir ve İslâm kültür ve düşüncesi üzerinden, yenilenmek ve genişletilmek suretiyle, İslâm düşünce perspektifi içinde devam eder. Çünkü İslâm düşüncesi, kültür ve medeniyeti, bu okuma ve izah etme şeklini kendi varlık tasavvur ve tahayyülüne daha uygun bulmuştur. Gerek sesler arasındaki ilişki zenginliği ve seslerin uyumlu kullanılıșı, gerekse insan ruhu üzerinde bıraktığı tesirler, düşünürleri mûsikî hakkında "Kosmosun bir ifadesi" yorumunu yapmaya yöneltmiştir. Çünkü kosmos, bu düşünürlere göre bir "Harmonia (uyum)" idi. Mûsikî de sesler arasında bir "Harmonia"yı yansıtmaktadır ve adeta kozmik harmoniayı ifade etmektedir. Bu düşüncenin sahibi Pythagoras'a göre kâinat, ilâhî bir özellik arzetmekteydi ve dolayısıyla iyi ve tek bir bütün olmak durumundaydı. Pythagoras, bugünkü müzik kurallarını ortaya koyan ve temellendiren kişi olmakla birlikte, mûsikî ilmine ve sanatına getirdiği kozmik yorumlarla da dikkat çekmektedir.

\section{Anahtar kelimeler}

\section{kosmos, harmonia, pythagoras, ihvân-ı safâ, gezegenler}

\section{İslâm mûsikîsini kozmik sembollerle izah etmek}

Mûsikîyi kâinat ile izah etmek, kadîm bir gelenektir. İslâm düşünce dünyasında da mûsikî, kozmik sembollerle ve varlıklarla açıklanır ancak bu açılklamalar tamamen İslâm düşünürlerinin geliștirdikleri orijinal bir açıklamadır, bu kadîm bir mûsikî öğretisidir ve İslâm kültür ve düşüncesi üzerinden, yenilenmek ve genişletilmek suretiyle, İslâm düşünce perspektifi içinde devam eder. Çünkü İslâm düşüncesi, kültür ve medeniyeti, bu okuma ve izah etme şeklini kendi varlık tasavvur ve tahayyülüne daha uygun bulmuştur. Mûsikîyi bu şekilde okuma biçiminin Batı'da St. Boethius ile sona erdiğini söyleyebiliriz. Aziz Boethius'un müziğe getirdiği yaklaşım, tam anlamıyla Pythagorien bir yaklaşımdır ve Pythagoras düşüncesinden etkilenmiş olduğunun açık bir göstergesidir. Aziz
Boethius'un özellikle "Musica Mundana (Göklerin, gezegenlerin müziği)" olarak açıklanabilecek yaklaşımı karakteristik Pythagorien bir yaklaşımdır ve kadîm müzik düşüncesinin Huristiyan dünyadaki önemli yansımasıdır. Aziz Boethius, müziğin yapısını incelediği özellikle Pythagoras'ın evrenin uyumu üzerine görüşlerini açıklamaya çalıştı̆̆ "De Institutione Musica" adlı beș ciltlik çalışmasının ilk dört cildini yine Gerasalı Nicomakhos'un "Harmonikon Enkhiridion" adlı yapitina, son cildini Ptolemaeus'un "Harmonica"sına dayandırmıştır [1].

Kâinattaki her şeyin döndüğü, feleklerin dönerken sesler, nağmeler çıkardığı bilgisi Pythagoras'a hatta onun yetiștiği ve Hermetik sırriyeti öğrendiği Mısır'daki Memphis Tapınăgı'na kadar gider. Fakat daha önemlisi, Hermetik kozmoloji doktrinine göre kâinatta her şey hareket halindedir ve Hermes'in (İslâm düşünür- 
lerine göre İdris Peygamber'in) Pythagoras'tan çok daha önce kâinatın, Allah'ın muhteşem bir bestesi olduğu fikrini ileri sürmüş olduğudur. İslâm düşünürleri, kendi kaynaklarında $\mathrm{Hz}$. İdris olarak zikrettikleri "Hermes"i, hikmetin kaynağı ve filozof ve bilgelerin ilki diye vasıflandırdılar. Şeyh el-İşrak (İşrâkî düşüncenin öncüsü) Şihâbuddin Suhreverdî ve talebesi Muhammed Şehrazûrî, onu Muteellihîn'de (İlâhî bilge) biri olarak kabul etmekteydiler. Suhreverdî'nin Mutârahat'ında Hermes bir koldan Asklepius, Pythagoras ve Platon ile Yunanlilar'a, diğer yandan ise Gayomarth, Feridun ve Keyhusrev ile İranlılar'a geçmiş ve sonunda İslâmî devirde İșrâkî okulun öğretilerinde bütünleşmiş olan hikmetin kaynağı olarak gösterilir [2].

Hermetizm'e göre kâinatta (kosmosta) boşluk dahî yoktur. Hatta Stoacılar ve Platoncular'ın tersine, kosmos ötesinde de (extra-kosmos) boșluk olmadığı, Hermetizm'in ileri sürdüğü bir görüștür [3]. O halde bu düșünceden hareketle biz de şunu söyleyebiliriz ki, boşluğun olmadığı ve hareketin olduğu her yerde cisimlerin titreşmeleri vardır ve bu titreşmeler sesi meydana getirir. Eğer kâinatta farklı boyutlarda cisimler, felekler (veya gezegenler) varsa, bunların hepsi kendi büyüklük veya küçüklükleriyle orantılı ve cüsselerine uygun olarak tiz veya pest sesler çıkaracaklardır. O halde kâinatta bu değişik boyutlardaki gezegenlerin çıkardıkları sesler vardır. (Bir de "Kâinattaki her şey kendi lisanlarınca Allah'ı zikretmektedirler" âyetini [4]hatırlayacak olursak, gerçekten kâinatta muhteșem bir ilâhi ahenkli melodi seslendiriliyor demektir) Hermes'in kâinattaki ahenkli melodiyi duyup bunu "Allah'ın bir kompozisyonu (bestesi)" olarak nitelendirmesi de belki buradan gelmektedir. Kâinatın sesleri ve feleklerin dönerken sesler veya nağmeler çıkardığı fikri antik Yunan'ın Aristo gibi akılcı filozofları ve İslâm dünyasında Aristo'ya tâbî olmuş Fârâbî gibi akılcı filozofları tarafından pek kabul görmese de, genel olarak benimsenmiş bir düşüncedir ve bu benimsemenin emârelerini daha ileriki yüzyıllardaki mûsikî nazariyatında da görmekteyiz. Meselâ İslâm Meşşâî filozoflarından biri olarak bilinen El-Kindî çalgı tellerini kâinatın hava, su, toprak ve ateş gibi dört unsuruna benzetmiş ve Mutlâku'l-Bamm, Sebbâbatu'lBamm, Vustâ el-Bamm (Bınsır), Hınsır elBamm (Mutlak el Müselles gibi), Sebbâbatu'l-Müselles, Vustâ el-Müselles (Bınsır), Hınsır el-Müselles (Mutlak el Müselles gibi) olmak üzere sesleri yediye ayırmıştır [5]. Bu yedi ses, yedi nağme ElKindî'ye göre gökyüzündeki yedi gezegene karşılık gelmektedir. Ayrıca mûsikî basamaklarını da onikiye ayıran Kindî, böylece mûsikî sanatını ve nazariyatını oldukça kozmik bir bilgiyle izah etmiştir. İslâm düşünce dünyasının iki önemli düşünürü Fârâbî ve İbn Sînâ'nın mûsikî yaklaşımlarında her ne kadar bu kozmik anlamlandırma olmasa da, İhvân-ı Safâ gibi Pythagorien düşüncenin etkisinde fazlasıyla kalan düşünce ekolü ve düşünürlerde mûsikîyi kozmik bilgiyle ve sembollerle izah etme yaklaşımına çok sık rastlarız. Hatta bu okuma biçimi, İslâm dünyasının en belirgin okuma biçimdir ve tasavvufu da etkilemiștir.

Bir makam hareketi de aslında bir dönüşü anlatmaktadır. Türk mûsikîsi ile ilgili yazılan kitaplar "Edvâr" olarak adlandırılır. Edvâr, "devirler, daireler" anlamına gelmektedir ve aslında mûsikînin dairevî hareketini de anlatmaktadır. Makâmın durağı ve duraktan başlanması, güçlüde muvakkat yani geçici karar yapılması, tiz durağa kadar seyretmesi, sonra tekrar inercesine aşağıya doğru yönelmesi, güçlüde tekrar muvakkat karar yapılması ve genellikle yeden perdesini kullanarak karar vermesi, genişlemeleriyle, inişçıkışlarıyla tam bir dairevî harekettir ve âdetâ gezegenlerin dönüșü gibi kozmik bir hareketi yansıtmaktadır. İnsan hayatının akışını da aslında feleklerin dönüşüne 
benzetmek mümkün olabilir: Bütün felekler döner. Aslında insan da döner ve insanın hayatı da bir dönüștür. Hayatına başladığı bir durak vardır, tıpkı bir makamın başlaması gibi insan da hayatına bir duraktan başlar, makamın seyri gibi gezinir, 40 yaş civarı, orta yaş olarak kabul edilir ve tıpkı makamın güçlüsüne karşılık olacak gibi önemli bir zaman dilimidir. Sonra yavaş yavaş yaşlanma sürecine girilir, tiz durağa doğru yönelinir ve artık iniş başlar. "Yaşlılık ikinci çocukluktur" sözüne uygun biçimde, adeta çocukken yaşadığı, makamın o başlangıç dönemlerini yaşar ve makâmın karar perdesinde "karar" kılar. Bunu şu ayetle açıklamayı uygun buluyor ve İslâm mûsikîsini de insanın ve bütün varlığın mutlak kaderinin mûsikîye yansıması olarak kabul ediyorum: "İnnâ lillâhi ve innâ ileyhi râciûn (Şüphesiz Allah'tanız ve yine O'na dönücüleriz)" [6]. İnsan hayatının özeti ve anlamı budur, sanat da hayatı yansıtıyorsa eğer, İslâm mûsikî sanatı da bu ayetin ifade ettiği mânâyı muhtevi olsa gerektir. İslâm mûsikîsinin dâirevî hareketinin, "İnnâ Lillâhi ve İnnâİleyhi Râciûn" ayetinin mûsikîdeki ifadesi olduğunu düşünüyorum.

$\mathrm{Bu}$ dairevî hareket, pekâlâ mûsikîdeki dairevî hareketi andırmaktadır. İnsan hayatı böyle dairevî bir harekettir. Çünkü insan, eski İslâm mütefekkirlerinin de ifade ettiği gibi "âlem-i sağîr" yani "küçük alem", yani "mikro kâinattır" ve kâinattaki diğer varlıklar gibi aslında döner ve bir gün bu dönüșü bitirip aslına rücû" eder. Mûsikîdeki dairevî hareket, insanın ve "makro insan" olarak kabul edilen kâinâtın dairevî hareketini, başladığı yere, geldiği yere dönüșünü sembolize etmektedir. Yani "İnnâ lillahi ve innâ ileyhi râciûn" ayetini ifade etmektedir.

\section{Kâinatın âhengi ve mûsikî}

Günümüz araştırmacıları tarafından "Fonetik sanatlar" kategorisine sokulan mûsikî [7], her ne kadar bağımsız bir di- siplin gibi görülmekte ise de, aslında "Kosmosun bir ifadesi" nitelendirmesini hak edecek önemi hâizdir. Nitekim mûsikînin bu boyutu hakkında Pythagoras ve Pythagoras Okulu mensuplarının yanısıra, İslâm düşünce dünyasında da bazı filozoflar görüş beyan etmişler, müstakil eserler kaleme, almışlardır.

Gerek sesler arasındaki ilişki zenginliği ve seslerin uyumlu kullanılışı, gerekse insan ruhu üzerinde biraktığı tesirler, düşünürleri mûsikî hakkında "Kosmosun bir ifadesi" yorumunu yapmaya yöneltmiştir. Çünkü kosmos, bu düşünürlere göre bir "Harmonia (uyum)" idi. Mûsikî de sesler arasında bir "Harmonia"yı yansıtmaktadır ve adeta kozmik harmoniayı ifade etmektedir.

Ancak, insanların büyük bir kısmı, bugüne kadar mûsikînin sadece mikrokozmik (insansal) görüntüsünü yakalayabildi. Oysa mûsikînin bu görüntüsünün ardında, çok daha güçlü bir "Makrokozmik (Evrensel)" özellik gizlidir ki, mûsikînin bu özelliği, insanların pek azının dikkatini çekebilmiştir. Sadece hikmete yönelen ve hikmetin arayışı içerisinde olan kimseler, mûsikînin sözkonusu makrokozmik boyutu ile ilgilendiler.

Mûsikîdeki makrokozmik boyuta ulaşabilmek için, önce mikrokozmik boyutu bilmek ve onu aşmak gerekiyor. Âleme yükseliș, insanın kendisine ait bilgiye vâkıf olmasıyla gerçekleşebilir.

"İnsan, kendini tanımakla âlemi de tanımış olacaktır. Çünkü o da tabiatın bir parçasıdır" [3]. Ve insan kendini tanıyıp bilmekle, Yaratıcısını da bilecektir. İnsan, bizzat kendi varlığının nüfuzuna varabilirse, küllî bilgiye, ona tabi diğer tüm ilimlere beraber varır. İnsan bunların prensiplerini kendinde aramalıdır. Çünkü o, varoluşun bir sembolüdür (el-İnsânu Remzu'l-Vücûd). Herșeyi yüce aslı içerisinde tanıyan bu yüce prensip dışında 
hiçbir şeyin bir hakikî gerçekliği olmadığını anlar [8].

Materyalist bir dünya görüşüne sahip olmalarına rağmen, Marksistler de insan fitratından gelen o sesle, insanın ulvî olana yönelmesi konusundaki fitrî baskılar karşısında çabaladığından, materyalist bir dil ile de olsa söz ederler. Onlara göre de insan kendini aşmak, sezip özlediği bir doluluğa doğru, daha anlamlı bir dünyaya geçmek için çabalamaktadır. İnsanların kitap okumaları, mûsikî dinlemeleri, eğlenmek istemenin ötesinde birtakım arayışlardan kaynaklanmaktadır. (...) "Belki de kendini aşmak istiyor insan. Tüm bir insan olmak istiyor, istiyor ki 'benliğinden' ötede, kendi dışında ama gene de kendi için vazgeçilmez birșeyin parçası olsun..." [9].

\section{Pythagoras'ın kosmosu}

Pythagoras'a göre kâinat, ilâhî bir özellik arzetmekteydi ve dolayısıyla iyi ve tek bir bütün olmak durumundaydı. "Eğer iyi, canlı ve bir bütün ise" diyordu Pythagoras, "kâinat sınırlanmış olduğu ve çeşitli parçaların birbirleriyle ilişkilerinde bir düzen sergilediği içindir." Kâinatın iyi ve canlı bir șey olduğu kadar, tek bir bütün olarak adlandırılabildiği tek anlam, onun değişmez sınırlara sahip ve düzenlemeye yetenekli olmasıdır. Kâinattaki her hareket son derece düzenlidir. Dönen yıldızların hepsi, ebedî ve mükemmel bir dairesel hareket içinde seyretmektedirler. Kâinat, kendisinde düzen, tamlık ve güzellik fikirlerini birleștiren, ancak modern Batı dillerine tam olarak çevrilemeyen "Kosmos (Kâinat)" sözcüğüyle adlandırılabilir. Pythagoras, kâinatı bu şekilde adlandıran ilk kişidir. Kosmos sözcüğü, Yunanlılar için de düzen ve güzellik demekti.

Kâinatın "Kosmos" ya da düzenli bir bütün olması gibi, Pythagoras'a göre biz insanlar da tıpkı kosmosun özelliklerini ihtiva eden küçük birer kosmosuz (mik- rokosmos). Biz insanlar olarak, büyük kâinatın (makrokosmos) yapısal ilkelerini, kendilerinde tekrar eden organizmalarız. Kâinatın yapısal ilkeleri üzerinde çalışmakla, kendimizdeki biçim ve düzen öğelerini geliştiririz. Kosmos üzerinde çalışan filozofun kendi ruhu da "Kosmios (düzenli)" hale gelir [10].

Pythagoras öğretisi daha çok kozmolojik bir karakter taşımaktadır. Bu kozmolojinin temel çizgileri ateş, su, toprak ve havadır. Bunlar başlangıçta bir kaos halinde vardı, sonra Tanrı bunları bir düzene soktu, kozmosu meydana getirdi [11].

Kozmostaki bu düzen ve uyumun bir yansımasıdır mûsikî. Veya mûsikîdeki uyum ve düzen, kosmostaki uyum ve düzenin bir ifadesidir.

\section{Pythagoras ve ilk mûsikî nazariyatı}

Mûsikînin temellerini kurmaya çalışan ve Nikomakhos tarafından, sesler arasındaki ilişkiyi ilk defa keşfettiği belirtilen Pythagoras'ın [12] mûsikî ile ilgili ilk bilgileri, bazıİslâm kaynaklarının ifadelerine göre Samos'lu bilgelerden öğrendiği rivayet edilmektedir. Samos'un lideri Androcolos'un Pythagoras'ı evlat edinerek, onun önce her Yunanlı gibi mûsikî, edebiyat ve dil öğrenmesi için girişimlerde bulunduğu, İslâmî kaynaklarda nakledilmektedir [13].

Kimi kaynaklarda ise, Pythagoras'ın Babil'de iken Zarbata adlı bir şahıstan ders aldığı, bu şahsın Pythagoras'a doğrular için gerekli olan şeyleri gösterdiği, varlığın sesini işittirdiği ve küllî (universal) ilkeleri bellettiği nakledilmektedir [13].

Pythagoras mûsikî üzerine "bilimsel" kabul edilen ilk çalışmaları yapan kimse olmakla, mûsikî biliminin de babası kabul edilir [14]. Pythagoras, mûsikî târihinde, mûsikîdeki oranların kurallarını, titreșen cisim (vücud) efektlerinin uzunluklarının nasıl değiştiğini, verdiği müziksel tonların perdeleri arasındaki farkı 
izah eden ilk kișidir [15]. Bugün bile, Pythagoras'a izafe edilen aralıkların temel kaideleri, en ufak bir değişikliğe uğramamiştır. O suretledir ki, Pythagoras zamanında 2:3 ile ifade edilen beşli aralığın kıymeti, bu kadar yüzyıl sonra aynı kalabilmektedir [16].

Pythagoras, uyumların değerini, sadece, onları meydana getiren tel uzunluklarının orantıları bakımından dikkate aldı. "Pythagoras gamı" adiyla anilan skala, aynı isimdeki sistemde, bir oktav aralığ na bir tabiî beşliler dizisini (Fa, do, sol, re, la, mi, si) meydana getiren sesler yerleştirilerek kurulur. Fizik ve mûsikî eserlerinde ancak Do majör tonunda gösterilen Pythagoras gamı pratik kullanım açısından elverişli kabul edilmese de, modüle edilmek suretiyle ve gerek yükselen diyezler dizisinden, gerekse alçalan bemoller dizisinden yararlanılarak bütün tonlara aktarılabilir. Telli saz icracıları, Pythagoras ilkesine uyarak çalarlar. Çünkü tellerini beşliden aralıklarla akort ederler. Bundan ötürü Pythagoras gamına "Kemancilar gamı" da denir ve bu gam "Piyanocular gamı (eşit ayarlı sistem)", "Solfej gamı (Mercator - Holder sistemi)"ndan ve "Fizikçiler gamı (Aristoksenes-Zarlino-Delezen sistemi)"ndan ayırt edilmiştir [17].

Dolayısıyla, bir "monochord (gerilmiș tel)" kullanarak hissedilen her ses arallğının mesafe oranını hesaplayan Pythagoras [18] ilk "Mûsikî bilgini" olarak kabul edilmektedir [19].

\section{Pythagoras'a göre mûsikî ve gezegen- ler}

Pythagoras, bugünkü müzik kurallarını ortaya koyan ve temellendiren kişi olmakla birlikte, mûsikî ilmine ve sanatına getirdiği kozmik yorumlarla da dikkat çekmektedir. Bu yorumlar, Pythagoras'ın belki de yetiștiği Hermetik bilgi geleneğinin etkisinde kalarak yaptığı yorumlar olabilir, ancak yine de mûsikîâhengini kozmik âheng ile izah etmesi ilgi çekicidir. Pythagoras'ın bu düşünce ve yorumları daha ziyade İslâm dünyasında karşılık bularak ilgi görmüştür. Onuncu yüzyıldan itibaren bazı islâmî kaynaklarda ve daha ileriki yüzyıllarda Osmanlı mûsikî çevrelerinde Pythagoras'ın görülen ve görülmeyen âlemleri seyrettiği, feleklerin yörüngelerinde dönerken çıkardıkları sesleri işittiği ve feleklerin ahengini dinlediği ileri sürülmektedir [13].

Osmanlı'da mûsikînin kozmik bir lisanla okunması ve izah edilmesine Sultan II. Murad döneminde yaşamış olan Bedri Dilşad ve onun 1441 yılında Sultan II. Murad'a ithaf ettiği "Muradnâme" adlı eserinde rastllyoruz. Bedri Dilşad "Muradnâme" adlı eserinin mûsikî bölümünde şöyle der:

"Bil evvel ki bu ilm-i İdris'dür Açık sözü sanma ki telbisdür Ânı dört ilimden çıkarmış tamam Alub birbirine karmış (eylemiș) tamam Onlar hey'et ü ilm-i hikmet nücûm Dahi tıb imiş söz beyânınıûm $\mathrm{Ki}$ oniki burca oniki makam Komuşlar ki seyreyleye mûdâm Yidi yıldıza yidi șu'be misâl Kodular ki eylenile imtisâl Anâsır nitekim olubdur çehâr Makâmın dâhi aslını anlar çâr Diyem ki üș makâmında fehm idesün Gerekmez ki fehmini vehm idesün" [20]

Osmanlı mûsikî çevrelerinde konu ile ilgili yorumlardan biri de, 1815 ve 1868 yılları arasında yaşamış olan Hâşim Bey'e aittir. Bu yoruma kaynaklık eden bilgilerin Hâşim Bey'e ulaşana kadar değișime uğradığını söyleyebiliriz. Zira Hâşim Bey'in yorumu dikkatlice okunup Pythagoras'ın düşüncesiyle karşılaştırıldığında bilginin zaman içinde değișime uğradığı veya orijinalliğini kaybettiği anlaşılabilecektir. Hâşim Bey, İlm-i Edvâr Risâlesi'nde Pythagoras'ı ve onun mûsikîșinas kişiliğini şöyle anlatır: "Fisagor hekîmin 
ilm-i mûsikîde mahâreti berkemâl olduğu, kuvve-i riyâziye sebebi ile hâsıl olup, bu cihetle Sedâ-i Evdâ Ecrâm-ı Semâviyeyi ve harekât-ı kevâkibi istimâ eyleyip derûnunda hifz ve ittikan ve bu terkip üzere 12 makam, 4 şube ve 24 terkib icad eylediği kütüb-i mûteberde mestûr ise de, Hoca Nasreddin ve Ebûali Sînâ 20 terkib, terkîbâtı mezkûrun üzerine zam ve ilâve ederek 44'de iblâğ etmişlerdir.

Hekîm-i mezbûrun ihtirâl olan makâmât ki, seyri edvâr-ı kadîm üzere bunlardır: Rast, Irak, Isfahan, Zîrekefend, Köçek, Büzürk, Zirgüle, Rehâvî, Hüseynî, Hicazbûselik, Neva, Uşşak.

12 burca nispetle $12^{\prime}$ ye hasredildi. Ve bu 7 âgâze ki Heft Âgâze tabir eylemişler, bunlardır: Geveșt, Şehnaz, Selmek, Mâye, Nevruz, Gerdâniye, Hisar, Seb'a-i Seyyâreye nisbet edip, Yegâh, Dügâh, Segâh, Çargâh yani çar şube tesmiye eylemişler [21]."

Pythagoras'ı mûsikî ilmi ile ilgilenmeye bu kadar yönelten, ilginç ve bilimsel uslûba pek de uymayan bir rivâyet vardır. Araştırmacılar, Pythagoras'ın bu olaydan sonra mûsikî ilminin anlamını kavradığını ve mûsikîye önem vererek, günümüze kadar ulaşan bilgilerin meydana gelmesi yolunda çaba sarfettiğini belirtirler. Pythagoras'ı mûsikî ile ilgilenmeye yönelttiği söylenen rivayet şöyledir: "Mûsikîyi îcad eden, Hz. Süleyman'ın talebelerinden biri olan Pythagoras'tır. Bir şahıs Pythagoras'a rüyasında üç gece üst üste şunları söylemişti: 'Kalk, falan denizin sahiline git. Orada garip bir ilim tahsil edeceksin.' Pythagoras, rüyanın etkisinde kalarak, tarif edilen yere gitmiş, ancak orada kimseyi bulamayınca bu rüyanın zâhirî mânâsının kastedilmediğine hükmederek demircileri toplayıp tenasüplü ve âhenkli bir şekilde çekiçlerini vurmalarını emretmiş, kendisi de bu sesler üzerine derin derin düşünmüş. Sonra dönerken sesler arasındaki oranların cinsleri üzerine düșünmüș, bu düşüncelerine ilâhî feyz ve Rabbânî ilham da eklenince, üzerine bir tek tel gerdiği bir âlet yapmış, ardından, tevhîde dâir inşâd ettiği şiirleri (münâcât) söylemeye başlamıș, halkı âhiretle ilgili işlere teşvik eden ilâhiler okuyarak, birçok kişinin dünya işlerini terk edip âhirete yönelmelerine vesîle olmuş. Pythagoras, kısa bir süre içinde saf bir cevhere sahip olduğu için riyâzât ilminde muhakkik bir hakîm olmuş, ruhların yurduna, ufukları geniş olan semâlara vâsıl olmuştu. 'Feleklerin hareketlerinden hâsıl olan câzib (șehiyye) nağmeleri ve güzel besteleri işitiyorum, bu terennümler, muhayyileme ve hâflzama yerleşmiștir' diyen Pythagoras, buna dayanarak bu ilmin kaidelerini ortaya koymuştur" [22].

Hz. Mevlânâ'nın da, kuyumcuların sesinden etkilendiği belirtilerek, Pythagoras ile aralarında benzerlik kurulur ve hem Hz. Mevlânâ'nın, hem de Pythagoras'ın, mûsikînin kaynağını, çıkış yerini, semâvî bir kaynakla izah ettikleri söylenir. Hatta Hz. Mevlânâ, Mesnevî'de şöyle der:

"Fakat padișahın rebab sesini dinlemeden maksadı, İştiyâk çekenler gibi hitâb-ı ilâhîyi hayâl etmekti. Zurna ve davul sesleri, bir parçacık o küllî neferin, Kıyâmet Günü'nde çalınacak olan Sûr'un sesine benzer. Hakîmler, bu mûsikî nağmelerini göklerin dönüşünden aldık demişlerdir..." [23].

Sûfîler, mûsikîyi haram sayanlara, $\mathrm{Hz}$. Mevlânâ'nın bu düşünce ve yorumlarıyla karşı koyuyor ve cevap veriyorlardı. Sûfîlerdeki yaygın inanca göre de, mûsikîyi icad eden Hz. Süleyman'ın talebesi Pythagoras'tır. Feleklerin dönerken çıkardıkları sesleri ișittikten sonra mûsikî ilminin öncülüğünü yapan Pythagoras, tasavvuf literatüründe de sıkça anılmaktadır [24].

$\mathrm{Bu}$ teori, zaman zaman mûsikî ile astroloji arasında ilişkiler kurulmasına da se- 
bep olmuştur. Mimar Mehmed Ağa'nın Risâle-i Mîmâriyye'sinde mûsikî-astroloji ilişkisine ışık tutacak nitelikte, şu bilgiler mevcuttur:

“(...) makamlar da 12'dir. Sekizinci göğün 12 burcu olduğundan, makamları 12 klsım üzere koymuşlardı. 12 burç dedikleri; kuzu, boğa, ikizler, yengeç, arslan, başak, terazi, akrep, yay, oğlak, kova, balık. 12 makam dedikleri; rast, isfahan, rrak, zîrefkend, büzürk, zengüle, rehavî, hüseynî, hicaz, buselik, neva ve uşşaktır. Bundan başka dört unsur vardır ki "anasır" dedikleri ateş, hava, su, toprak. Şube de dörttür. Şubeyi de dört unsura göre koymuşlardır. Yegâh, dügâh, segâh, çargâh. En aşağı mertebe yegâhtır, yukarı mertebe ise çargâhtır. Dügâh ve segâh, bu ikisinin arasındadır. Ve gezegenler de 7'dir. Zuhâl, Müşteri, Merih, Şems, Zühre, Utarit, Kamer. Âvâze de yedidir. Zira âvâzeyi 7 gezegene göre koymuşlardır. 7 âvâze dedikleri ise; nevruz, selmek, şehnaz, mâye, gerdâniye, hicaz, geveșt.

Bundan başka, gece ve gündüz 24 saattir. "Terkîbat da 24'tür. Zira terkîbâtı 24 saate göre koymuşlardır. Bir makamı âğâz edüp, yani başlayup baskasında karar edince, onda bir terkib elde edilir ve bu ilme de "Edvâr İlmi" ve "Mûsikî ilmi" derler. (...) Bu ilmi yazıp düzenleyen, $\mathrm{Hz}$. Süleyman'ın talebelerinden, hakîm Pythagoras'tır. Söz birliği ile 7 hakîmin en seçkinidir. Deniz dalgalarının vuruşundan, yani sı̆̆ yerlerde denizin talazından, birbirinin ardından gelüp taşra kıyıya vurmasından usuller bulup, yazup dizmiştir" [24].

Mehmed Ali Aynî de feleklerin dönüşünden bir nağmenin hasıl olduğunu şu şekilde beyan etmektedir: "Eski astronomiye göre sayıları yedi olan felekler, şeffaf kubbeler halinde birbirinin mihveri etrafında dönerler. Dönerlerken de, nehirden su çekip bağ ve bahçelere akıtan dolaplar gibi sesler çıkarırlar. Göklerin ve feleklerin dönüșünden hâsıl olan lâtif ve ruhnuvâz nağmeleri, lâhûtî mûsikîyi herkes işitemez. Bu nağmeleri, uzun bir çalışmadan ve gayretten sonra filozof Pythagoras işitmiş ve onun sayesinde mûsikî kâidelerini ortaya koymuștur" [25].

İhvân-ı Safâ'nın önemli öncülerinden biri olan Pythagoras, mûsikî ilminin, kurucusu olarak kabul edilir. Pythagoras'ın ve Pythagorasçılar'ın mûsikî anlayışlarının da İhvân-ı Safâ üzerinde şüphesiz tesirleri olmuştur.

\section{Pythagoras kosmosu: uyumlu sesler veren bir "birlik"... "kâinat uyum ile sayıdır"}

Pythagoras'ın düşünce sisteminde sayılar, mûsikî içinde de ifadesini buluyordu. Onun en çarpıcı düşünceleri, mûsikî hakkındaydı. Pythagoras, mûsikî gamının, halen mükemmel ses uygunlukları olarak adlandırılan (iki ses arasındaki) yerde farklarının $1,2,3$ ve 4 sayılarının oranları olarak, aritmetiksel bir biçimde dile getirilebileceğini düşündü. Bunlar birbirlerine eklendiklerinde 10 yapan sayllardır ve 10 sayısı, matematik ve gizemcilik (mistisizm) unsurlarından meydana gelen alıșılmadık karıșımda, mükemmel sayı olarak kabul edilir. Bu sayı, geometrik bir biçimde, "Tetraktys" adı verilen şekille gösteriliyordu. Oktav (sekiz notalı yapı) 2:1 oranıla, bir notada beş derece tiz ya da pest olan ara 3:2 oranıyla, do ile fa arasındaki ara 4:3 oranıyla üretilmekteydi. Pythagoras, kosmosun bir "harmonia"yı (uyumu) ifade ettiğini belirtmiştir. Harmonia, öncelikle mûsikî alanına uygulanmıştır [10].

Mûsikîde sayıların önemini ortaya koyan, Pythagoras'tır ve onun mûsikî ile matematik arasında kurduğu bağlantı, "Uyuşumsal Orta", "Uyuşumsal Gelişme" gibi matematik terimlerinde yaşamaktadır [26]. 
Müsikîdeki harmonia da sayıya dayanmaktadır [27]. Çünkü tellerin veya borunun uzunluğu ile çıkan ses arasında bir ilişki vardır [28] düşüncesini Pythagoras, gezegenlere de uyguluyor ve böylece kosmos, ona göre uyumlu sesler veren bir birlik oluyordu [29]. Pythagoras'a göre en güzel şey harmoniadır (uyum). Bütün kâinat uyum ile sayıdır [30]. (Aristoteles aktarıyor): Bazılarına göre, gezegenler hareket ederken ses çıkarırlar. Güneş ile ay ve sayıca ve yığınca bu denli büyük olan yıldızların, bu hızla ve bu dönüşle ses çıkarmamaları düşünülemez. Bunları ve bir de (ayrı ayrı) aralıklara dayanan hızların mûsikîce bağıntıları olduğunu kabullendiklerinden, yıldızların çepeçevre dönmelerinden doğan sesin harmonialı olduğunu söylüyorlar.

Pythagorasçılar'a göre bütün kosmosa harmonia, quarte, quinte ve oktave hükmeder. (Bu intervallumlar [aralıklar] ilk dört sayı ile kuruluyorlar. Zira 1:2 oranı oktaveyi, 2:3 quinteyi, 3:4 quarteyi verir.) Pythagoras'ın kendisi, bütün evrenin ahengini dinliyordu. Çünkü o kürelerin ve bunlar üzerinde dönen yıldızların hep birlikteki uyumunu anlıyordu [29].

Eski Yunan, Pythagoras sayesinde aralıkları tanır olmuştu. Bugün sahip olunan bazı teknik ifadelerin kaynağı, Eski Yunan'da idi. Ton, diatonik sisteme, yarım ton kromatik sisteme, çeyrek ton da anarmonik sisteme kaynaklık ediyordu denilebilir [31].

\section{Gezegenlerin sesleri ud nağmeleri gibidir}

İhvân-ı Safâ, gezegenlerin hareket ederken nağmeler çıkardıklarını söylerken, Pythagoras düșüncesine oldukça yaklaşmaktadırlar. İhvân'ın bu düşüncelerinin, Pythagoras'ın "Gezegenlerin hareketleri esnasında ses çıkardıklarına dâir" düșüncelerinin biraz daha geliștirilmiș șekli olduğu düşünülebilir. Pythagoras, feleklerin hareketlerinden hâsıl olan câzib nağmeleri ve güzel besteleri işittiğini, bu terennümlerin muhayyilesine ve hâfızasına yerleştiğini söylemekteydi [22].

Pythagoras'ı Harran'lı hikmet sâhibi bir muvahhid olarak kabul eden ve bunu Risâleler'in 3. cildinin 200. sahifesinde belirten İhvân-ı Safâ, bu filozofun kendileri üzerindeki tesirinden söz ederken [32], bu tesirin sonucu olarak, gezegenlerin hareketleri esnasında çıkardıkları nağmeler hakkında da şunları söylüyor: "Kardeșim (Allah seni ve bizleri gücüyle desteklesin.) gezegenlerde yaşayan varlıkların hareketlerinin ses ve nağmeleri olmasaydı, kendilerinde bulunan ișitme duyusunun hiçbir faydası kalmazdı. İşitme duyuları olmasaydı, varlıkları eksik olan hareketsiz canlılar gibi sağır, dilsiz ve kör olurlardı. Felsefi mantık yoluyla elde edilen sahih deliller gösteriyor ki, göklerde ve gezegenlerde yaşayanlar, Allah'ın işiten, gören, düşünen, bilen, okuyan, gece ve gündüz bikmadan onu tesbih eden melekleri ve ihlasl kullarıdır. Tesbihleri, Hz. Dâvûd'un mihrabda Zebur'u okumasından daha tatlı, Kisra'nın saraylarında çalınan fasih ud nağmelerinden daha güzeldir. Eğer onlarda da koku ve tad alma ve dokunma hislerinin bulunması gerektiği iddia edilirse deriz ki; koku ve tad alma ve dokunma hisleri, ancak yemek yiyip su içen canlılara, faydalıyı zararlıdan ayırabilmeleri ve vücudlarını öldürücü ve zarar verici sıcak ve soğuktan korumaları amacıyla verilmiştir. Göklerin ve gezegenlerin halkı ise, bunlara ihtiyacı olmayan varlıklardır. Onların yemek yemeye ve içmeye ihtiyaçları yoktur. Onların gıdaları tesbîh, içecekleri tehlîl (Lâilâhe İllallah demek), meyveleri tefekkür, araştırma, bilgi, bilinç, marifet, ihsas, lezzet, ferahlık, mutluluk ve rahatlıktır. Gezegen ve yıldız hareketlerinin, güzel, tatlı ve ruhlara ferahlık veren nağme ve melodileri vardır. Bu nağme ve melodiler, orada bulunan basit ruhlara, gezegenler âleminin cevherlerinden daha üstün ve şerefli cev- 
herlere sâhip olan yörüngenin üstünde bulunan ruhlar âleminin mutluluğunu hatırlatıyor. Bu ruhlar âlemi, Allah'ın Kur'ân'da bildirdiği ve ancak cennette bulunan güzel koku ve rahatlık nimetlerine sâhip olan hayattır. Anlattıklarımızın doğruluğuna ve özelliklerini bildirdiğimiz hakikatlere delil olarak şunları söyleyebiliriz: Müzisyenin hareketlerinden çıkan nağmeler, kevn ve fesad âlemindeki canlılara, gezegenler âleminin mutluluğunu hatırlatır. Gezegen ve yıldız hareketlerinin nağmeleri de, oradaki canlılara ruhlar âleminin mutluluğunu hatırlatır. $\mathrm{Bu}$ da uzmanlarca bilinen öncüllerden ortaya çıkan sonuçtur. Onlara göre ikinci derecede illetli varlıkların durumu, sebep oldukları ilk varlıkların durumuna benzer. Bu bir mukaddimedir, diğeri ise şu sözleridir: Felekî şahıslar, kevn ve fesad âlemindeki bu varlıkların ilk sebepleridirler. Hareketleri, bunun hareketlerinin sebebidir. Bunun hareketi diğerinin hareketine benzer. Mecbûrî olarak nağmeleri de onun nağmeleri gibidir. Buna, çocukların oyun oynarken yaptıkları hareketleri örnek verebiliriz. Çocukların davranışları, anne-babalarının davranışlarına benzer. Öğrenciler de davranışlarında, hocalarına benzerler. Bu konuda kafa yoranlar bilirler ki, felekî varlıklar ve düzenli hareketleri, ay gezegeni altındaki canlılara göre daha öncedir, hareketleri de bunun hareketinin sebebidir. Ruhlar âlemi de, bedenler âleminden daha öncedir" [32].

ihvân-ı Safâ, Pythagoras'ın gezegenlerin nağmelerini duyduğunu, daha sonra da bazı filozofların mûsikî konusunda birtakım görüşler ileri sürdüklerini belirterek, şunları söylemektedir: "Çocukların tabiatında ana-babanın tavırlarına, öğrencilerin tabiatında hocalarının tavırlarına, halkın tabiatında idarecilerin tavırlarına, akledenlerin tabiatında da meleklerin durumlarına arzu duyma ve onlara benzeme duygusu olduğu gibi, yaratılıs âleminde uyumlu nağmeleri olan düzenli hareketlerin bulunması, gezegenler âleminde de uyumlu nağmeleri olan düzenli hareketlerin bulunması, gezegenler âleminde de bu bitişik ve muntazam hareketlerin uyumlu, nefisleri ferahlatan ve daha yükseklerdekini arzulayan nağmeler bulunduğunu gösterir. Felsefe konusunda da belirtildiği gibi, bu, insanın gücü nisbetinde ilâha benzemesidir. Fisagor, kendi saf nefis cevheriyle ve kalbinin zekâsıyla yıldız ve gezegen hareketlerinin nağmelerini duymuş ve yaradılışının kendisine bahşettiği cömertlikle mûsikî usullerini ve nağmeleri ortaya çıkarmıştır [12] [15] [14]. Filozoflar içinde bu konuda ilk defa görüş serdeden ve bu sırrı haber veren de o olmuştur. Ondan sonra Nikomakhus, Batlamyus, Oklid ve diğerleri gelir. Bu ise, filozofların, mûsikî notalarını ve tellerin nağmelerini, mâbedlerde, ibâdethânelerde, özellikle de hüzün veren, katı kalpleri yumuşatan, gâfil nefsleri, oyun ve eğlenceye dalıp rûhânî âleminin, nûrânî yerinin ve hayat evinin mutluluğundan gâfil olan ruhları uyaran notaları kullanmalarının sonucuydu.

ilâhiyatçı filozoflar mûsikîyi, mâbed ve ibâdethânelerde, katı kalpleri yumuşatmak, gâfil nefsleri, cehâlet yatağında oyalanan ruhları gaflet uykusundan uyandırıp rûhânî âlemlerine, nûrânî yerlerine, cennetteki hayat evlerine doğru teşvik etmek, onları kevn ve fesad âleminden çıkarmak, onları tabiata esir olmaktan kurtarmak amacıyla kullanırlardı ve mûsikîlerinde ve şiirlerinde, insanları bu amaçları doğrultusunda harekete geçirebilecek nitelikte sözler veya nağmeler zikrederlerdi. Mûsikînin bazı peygamberlerin şeriatlarında haram kılınmasının sebebi ise, insanların onu, filozofların kullandıkları amacın dışında, oyun, eğlence, dünyanın lezzet ve şehvetleri ve dünya kuruntularıyla aldanma yolunda kullanmalarından kaynaklanmaktadır..." [32].

ihvân-ı Safâ, bu bölümde müzisyen filozofların, Ud'un tel sayısını niçin dört ola- 
rak belirlediklerini açıklıyor. Bunu açıklarken, yine Pythagoras'ın kosmos anlayışının yansımalarına rastlamaktayız [11].

"Müzisyen filozofların, Ud'un tellerinin sayısını da daha az veya daha çok değil de, dört olarak belirlemelerinin sebebi, 'Aritmetik' kitapçığında da açıkladığımız gibi, yaptıklarının, Yüce Allah'ın hükmüne uyarak Ay'ın aşağısındaki tabiî duruma uygun olmasını sağlamaktır. Zîr teli, ateş unsuruna denktir ve nağmesi de onun sıcaklık şiddetine uymaktadır. Mesnâ teli, hava unsuruna denktir ve nağmesi de havanın nem ve yumuşaklığına uygundur. Misles teli su unsuruna denktir ve nağmesi de suyun yaşlık ve soğukluğuna uygundur. Bam teli, yer unsuruna denktir ve nağmesi de yerin ağırlık ve kalınlığına uygundur. $\mathrm{Bu}$ özelliklerin birbirleriyle ilgileri ve nağmelerinin, dinleyicilerin mîzâcına göre etkileri vardır. Çünkü Zîr nağmesi, safra salgısını güçlendirip, kuvvet ve etkisini artırır, balgam salgısına karşıttır ve onu yumuşatır. Mesnâ nağmesi, kan salgısını güçlendirip kuvvet ve tesirini artırır. Sevda salgısına zıddır, onu inceltir ve yumuşatır. Misles nağmesi balgam salgısını güçlendirir, kuvvet ve etkisini artırır, safra salgısına zıddır, şiddetini kırar. Bam nağmesi, sevda salgısını güçlendirir, kuvvet ve tesirini artırır. Kan salgısına zıddır, feverânını sakinleştirir. Bu nağmeler biraraya getirilip notalarda şekillendikleri zaman, büyük hastalıklar ve ârızî illetler gibi olan karşıt gece ve gündüz vakitlerinde kullanıldıklarında, onları sakinleştirir, şiddetini kırar ve hastanın acılarını hafifletir. Çünkü huyda şekillenmiş olan şeyler çoğalıp toplandığında yaptıkları güçlenir, etkileri ortaya çıkar ve insanların savaşta yaptıkları gibi, karşıtlarını yenerler.

Şimdiye kadar anlattıklarımızdan, mûsikî bilginlerinin, mûsikîyi hastanelerde, hastalık araz ve illetlerinin tabiatına zıd zamanlarda kullanmalarının sebeb-i hikmeti anlaşılmıştır. Onlar, ne daha çok ve ne de daha az, sadece dört tel kullanmakla yetinmişlerdir. Her telin kalınlığını, bir öncekinin 1+1/3 misli yapmalarının sebebi de, yüce Yaratıcı'nın hikmetine uymak ve tabiî yaratıkları yaratmasının izlerine uygun hareket etmektir. Çünkü tabiatçı filozoflar, dört ana unsur olan ateş, hava, su ve yerin (toprak) her birinin çaplarının keyfiyette yani yumuşaklık ve kalınlıkta bir alttakinin 1+1/3 misli olduğunu söylemişlerdir. Ve demişlerdir ki; esir küresi yani Ay gezegeninin aşağısında olan ateş küresinin çapı, zemherir küresinin çapının $1+1 / 3$ mislidir. Zemherir küresinin çapı, Nesim küresinin çapının 1+1/3 mislidir. Nesim küresinin çapı su küresinin, su küresinin çapı da aynı şekilde yer küresinin çapının 1+1/3 mislidir. Bu oranların anlamışudur: Ateş cevheri şeffaflıkta hava cevherinin, hava cevheri su cevherinin, su cevheri ise yer cevherinin 1+1/3 mislidir. Kendisi ateş unsuruna, nağmesi ateşin sıcaklık ve şiddetine denk olan Zîr telini bütün tellerin altına, yer unsuruna denk olan Bam telini, hepsinin üstünde, Mesnâ'yı, Zîr'i takib eden yere, Misles'i de Bam'ı takib eden yere çekmelerine gelince bunun da iki sebebi vardır:

Birincisi: Zîr'in nağmesi, keskin ve hafiftir, yukarı doğru hareket eder. Bam’ın nağmesi ise kalın ve ağır olup aşağıya doğru hareket eder. $\mathrm{Bu}$ da mîzaçlarına ve beraberliklerine daha uygundur. Mesna ve Misles de böyledir.

ikincisi: Zîr'in Mesnâ'ya, Mesnâ'nın Misles'e, Misles'in Bam teline oranla kalınlıkları, yerin çapının Nesim küresinin çapına, nesim küresinin zemherir küresine ve zemheririn esir'e oranları kadardır. Iste telleri bu sıraya göre çekmelerinin sebebi de bu uyumu bozmamaktır.

Tellerin nağmelerinde $1 / 5,1 / 6$ ve $1 / 7$ oranlarını kullanmayıp sadece $1 / 8$ oranını kullanıp onu tercih etmelerinin sebebi, diğerlerinin hepsinin ondan türemiş ol- 
malarıdır. Sekiz, ilk küp sayıdır. Aynı şekilde altı sayısı ilk tam sayı olduğu için şekillerin de altı yüzü olduğundan, bunlar için en uygunudur. Altıdan önce gelen ise küptür. Çünkü "Geometri" kitapçığında da açıkladığımız gibi, küpte denge vardır. $\mathrm{Bu}$ şeklin boyu, eni ve derinliği hepsi birbirine eşittir. Hepsi birbirine eşit, kare şeklinde altı yüzü vardır. Hepsi de eşit ölçüde, sekiz açılı, oniki dengeli ve eşit kenarlı, yine birbirine eşit yirmidört dikaçılıdır. Yirmidört sayısı da üç ile sekizin çarpımının sonucudur. Daha önce içinde çokça eşitlik olan şeylerin, daha değerli olduklarını söylemiştik. Küreden sonra küpten daha çok eşitliğe sahip başka bir şekil yoktur. Bu sebepledir ki, Oklid'in kitabının son makalesinde, yeryüzünün şekli küp'e daha çok benzer, gezegenin şekli de oniki ayaklı, beşli bir şekli andırır denilmiştir.

Sekiz sayısının üstünlüğü hakkında matematik bilginlerinin söylediği bazı şeyler vardır. Şöyle ki: Gezegen küreleri ile yeryüzü ve havanın çapları arasında "Müziksel" bir oran vardır. Yeryüzünün yarıçapı sekiz, hava küresinin çapı dokuz olduğunda, Ay gezegeninin çapı 12, Utarid gezegeninin çapı 13, Zühre'nin çapı 16, Güneş'in çapı 18, Merih'in çapı 21,5, Müşteri gezegeninin çapı 24, Zuhal gezegeninin çapı 27, sabit yıldızlar yörüngesinin çapı ise 32 'dir. Ay gezegeninin çapı, yer gezegeninin $1+1 / 3$ mislidir. Havanın çapının 1+1/4 mislidir. Zühre'nin çapı, Yer'in çapının iki katı, Ay'ın çapının $1+1 / 3$ mislidir. Güneş'in çapı havanın çapının iki katı, yerin çapının $2+1 / 4$ mislidir. Ay'ın çapının ise birbuçuk katıdır. Müşterinin çapı, Ay'ın çapının iki katı, Yer'in çapının üç katı, Zühre'nin çapının birbuçuk katıdır. Sabit yıldızlar yörüngesinin çapı, müşterinin çapının 1+1/4 misli, Zühre'nin çapının ise iki mislidir. Güneş'in çapının 1+3/4 mislidir, Ay'ın çapının 2+3/4 misli, Yer'in çapının dört katıdır. Ama Utarid, Merih ve Zuhal, bu oranların dışındadır. Bu sebeple bunlara uğursuz denmiştir. Bilginler bu yıldızların kütlelerinin büyüklükleri arasında da farklı oranlar olduğunu söylemişlerdir. Bu oranlar ya sayısal, ya geometrik ya da müziksel olup, yıldızlarla yeryüzü arasında da mevcuttur. Bazılarıüstün ve değerli, bazıları ise değildir.

$\mathrm{Bu}$ anlattıklarımızdan, gezegenleriyle, yıldızlarıyla, dört unsuruyla, birbirlerinden oluşan terkibiyle dünyanın cisminin bütününün, bu mezkûr oranlarda birbirlerinden yapılmış, biraraya getirilmiş ve birbirlerinden meydana gelmiş olduğu anlaşılmıştır..." [32].

\section{Feleklerin nağmelerinin hakikati üzerine}

İslâm dünyasında Pythagoras'ın düşüncelerini benimseyen düşünür grubu ihvân-ı Safâ'dır ve bu topluluk, 52 risaleden müteşeklkil ansiklopedi mahiyetindeki eserlerinde mûsikî için özel bir risâle kaleme almışlar ve bu mûsikî risâlesinde Pythagoras'ın mûsikî konusundaki düşüncelerinden mülhem düşünceler geliştirmişlerdir. ihvân-ı Safâ da tıpkı Pyhtagoras gibi kâinatın uyum (harmonia) olduğundan sözeder.

ihvân-ı Safâ, kâinattaki yaratıklar arasındaki uyumdan ve oranlardan söz ettikten sonra, aynı uyumun gezegenler arasında da var olduğunu belirtir ve gezegenlerin bu uyumlu hareketleri sırasında oldukça uyumlu nağmeler çıkardıklarını ifade eder. ihvân'ın, gezegenlerin (feleklerin) çıkardığı nağmelerin hakîkatleri konusundaki görüşleri şöyledir: "Ey kardeşim (Allah seni ve bizi kendinden bir ruhla desteklesin), bil ki, yukarıda sözü geçen fasıllarda ortaya konan 'En sağlam sanatlar, en kavî terkibler ve en güzel te'lifler, iskeletinin ve cüzlerinin te'lifi; ideal orana göre yapılanlardır' hükmü düşünüldüğünde, her akıllı mütefekkir için delil ve kıyas şunu gerektirir: Feleklerin ve uydularının terkîbi, büyüklükleri, erkanı 
ve doğuşları da bir diğerine göre, ideal oran doğrultusunda yapılmıştır. Bu gezegenlerin uzaklıkları, uyduları ve hareketleri de ideal oranla uyum içerisindedir. $\mathrm{Bu}$ uyumlu hareketlerin de yine uyumlu, çarpıcı ve leziz nağmeleri vardır... ud tellerinin hareketleri ve nağmeleri faslında açıkladığımız gibi. Akıl sâhibi kimse düşündüğü zaman, bunları Sânî-i Hakîm'in yaptığını, usta bir Mürekkibin terkîb ve Lâtîf bir Müellifin te'lîf ettiğini anlar. Şüphelerden böylece arınır, hak kendisine açılır. Bu feleklerin hareketlerinde ve bu hareketler sonucu çıkan nağmelerde, ehli için lezzet ve sevinç olduğuna inanır. Nasıl ki Ud telleri bu âlemde ehline lezzet ve sürûr veren nağmeler çıkarıyorsa. işte o zaman bunların farkına varan kimsenin nefsi, oraya yükselmek. Onu dinlemek ve onu görmek ister. Tıpkı Hermes'in nefsinin saflaşıp, bunu görünce hikmetle yükselişi gibi... O(nun) idris Nebî'dir (olduğu söyleniyor). Şu ayette O'na işaret edilmektedir: 'Biz onu yüce bir mekâna kaldırdık...' [33]. Yine hakîm Fisagor'un; cismânî şehvetlerden arınıp dâimî fikirler ve sayısal, hendesî ve müziksel riyâzetlerle donandığı vakit bunu duyduğu gibi..." [32].

ihvân-ı Safâ, daha sonra kişiyi nefsini arındırmaya, onu heyulâ denizinden, tabiatın esaretinden ve cismânîşehvetlerin kulluğundan kurtulmaya çağırır. Kişiye ölümü hatırlatarak, gerçek kurtuluşa davet eder. Daha sonra da, tekrar konuya dönerek, Arap mûsikîsi hakkında bilgiler vermeye başlar.

\section{Sonuç}

Mûsikî sanatının insanoğlunun yeryüzünde sıradan eğlencelerinin aracı olmadığını ve bu sanatın varlıktaki âhengin yansıması olduğunu izah etmeye çalışan düşünce ve yaklaşım, aslında Hermes/Hz. idris'e kadar uzanan kadîm bir düşünce ve yaklaşım olmakla birlikte, bu düşüncenin i̇slâm medeniyeti içerisinde gelişti- ğini ifade edebiliriz. Bu düşünce biçimi, mûsikî sanatında neredeyse her sesin ve makamın veya nağmenin kâinatın ahengli yapısı içerisinde bir karşılığı olduğunu anlatmaya çalışmaktadır. Dikkat çekici olan da, İslâmiyet'ten önce Pythagoras gibi düşünürlerin mûsikî hakkında ortaya koyduğu düşünce ve kozmik okuma ve izah biçimiyle, Müslüman düşünürlerin kolay irtibat kurmaları ve bu kadîm düşünce biçimine zenginleştirici katkılarda bulunmalarıdır. Antik Yunan düşüncesinin yanısıra, başka kültürlerin ortaya koyduğu düşünce birikimini Kur'an süzgecinden geçirerek yeniden yorumlayan İslâm düşünürleri, mûsikî hakkındaki düşüncelere karşı da ilgisiz kalmamış, ilgisiz kalmadıkları gibi, bu düşüncelere katkıda bulunarak geliştirmişlerdir. Düşünce sistemlerini Kur'an merkezli ve hakikat eksenli inşâ eden İslâm düşünürlerinin, kadîm mûsikî düşüncesinde Kur'an'a ve hakikate uygun yaklaşımlar buldukları muhakkak. Eğer böyle olmasaydı, kadîm mûsikî düşüncesi ile kaynaşmak ve onun üzerinde yeniden çalışarak geliştirmek mümkün olmaz, bunun üzerinde yükselen bir i̇slâm mûsikî düşüncesi de ortaya çıkmazdı. İslâm mûsikî düşünürlerinin, bu kadîm düşünce mirasını ciddiye aldıkları ve mirası tüketmek yerine geliştirdiklerini anlayabiliyoruz. Öyle ki, zayıf bilgilerle kendilerine ulaşan kadîm mûsikî düşüncesini geliştirerek ortaya koydukları i̇slâm mûsikî düşüncesi, bugün bile hayli heyecan verici, orijinal ve üzerinde yeniden çalışarak geliştirilmeye açık bir mûsikî düşüncesi olma özelliğine sahiptir. Bu çalışma, mûsikî düşüncesinin kosmos/kâinat ile ilişkilendirildiği ilk dönemlere kadar inmeye çalışarak bu düşünce biçimini ortaya koymaya ve i̇slâm düşünürleri tarafından nasıl ele alınarak geliştirildiğini göstermeye çalışan bir çalışmadır. 


\section{Kaynaklar}

[1] H. B. Chadwick, The Consolations of Music, Logic, Theology and Philosophy, Oxford: Oxford University Press, 1991, p. 19.

[2] S. H. Nasr, isslâm'da Düşünce ve Hayat, istanbul: İnsan Yayınları, 1988, p. 153.

[3] M. E. Kılıç, ìslâm Kaynakları Işığında Hermes ve Hermetik Düşünce, istanbul: Basılmamış YL tezi Marmara Üniversitesi, 1990, p. 147.

[4] KK, Kur'ân-ı Kerîm, Haşr Sûresi, 1. âyeti kerîme.

[5] R. Kalender, Zeynu'l-Elhân fî ilmi'tTe'lîf ve'l-Evzân, Ankara: AÜ. Basılmamış doktora tezi., 1982, pp. 170, 173, 176.

[6] KK, Kur'ân-ı Kerîm, Bakara Sûresi, 156. Âyet-i kerîme.

[7] S. Mülâyim, Sanata Giriş, istanbul: Sanat Tarihi Araştırmaları Dergisi Yayınları, 1989.

[8] R. Guenon, Quelques Considerations Sur L'Hermetisme, Paris.

[9] E. Fischer, Sanatın Gerekliliği, ìstanbul: Özgür Yayınları, 1974.

[10] W. Guthrie, ilkçağ Felsefesi, Ankara: Gündoğan Yayınları, 1988.

[11] i. Tunalı, Grek Estetiki, istanbul: Remzi Kitabevi, 1983.

[12] F. Rosenthal, The Classical Heritage in Islam, London: Rotledge and Keagan Paul, 1975.

[13] B. Karlıga, islâm Kaynakları ve
Filozofları Işıı̆ında Pythagoras ve Presokratik Filozoflar, istanbul: istanbul Üniversitesi Basılmamış Doktora Tezi, 1980.

[14] W. Pole, The Philosophy of Music, London, 1924.

[15] H. D. M. Kinney ve W. Anderson, Music in History, USA: Three Volution of an Art, 1954.

[16] R. Y. Bey, Türk Mûsikîsi, ìstanbul: Pan Yayıncilık, 1986.

[17] M. Larousse, Meydan Larousse, istanbul: Meydan Yayınevi, 1973.

[18] E. Çelebioğlu, Tarihsel Açıdan Evrensel Müziğe Giriş, ìstanbul: Üçdal Neşriyat, 1986.

[19] i. Mimaroğlu, Müzik Tarihi, isstanbul: Varlık Yayınları, 1987.

[20] B. Dilşad, Muradname, istanbul: MEB Yayınları, 1997.

[21] H. Bey, ilm-i Edvâr Risâlesi, Ankara: AKM Yayını, 2016.

[22] B. R. D'Erlanger, La Musique Arabe, Paris: Paul Geuthner, 1930.

[23] M. C. Rumi, Mesnevî, istanbul: MEB Yayınları, 1988.

[24] B. Ayvazoğlu, ìslâm Estetiği ve insan, İstanbul: Çağ Yayınları, 1989.

[25] M. A. Aynî, Intikad ve Mülâhazalar, İstanbul , 1923.

[26] B. Russell, Batı Felsefesi tarihi, Ankara: Bilgi Yayınevi, 1972.

[27] M. Gökberk, Felsefe Tarihi, istanbul: Remzi Kitabevi, 1985. 
[28] S. H. Bolay, Felsefî Doktrinler Sözlüğü, isstanbul: Akçağ Yayınları, 1990.

[29] W. Kranz, Antik Felsefe, istanbul: Sosyal Yayınlar, 1984.

[30] F. Copleston, Felsefe Tarihi, istanbul: idea Yayınları, 1986.

[31] H. Lavoix, Histoire de la Musique, Paris, 1955.
[32] i̇.-ı. Safâ, Resâil, Beyrut,: Dâru's-Sadr, 1957.

[33] KK, Kur'ân-ı Kerîm, Meryem sûresi, 57. âyet-i kerîme. 


\section{From the motion of planets to the tunes of music}

\section{Extended abstract}

Explaining music with reference to the universe is an ancient tradition. In the Islamic thought, music is understood through cosmic symbols and beings, however, these understandings are completely original and developed by Muslim thinkers. This is an ancient teaching in the science of music and it continues to thrive and develop within the perspective of Islamic thought. Islamic thought, culture and civilizations have favored this method of understanding and explaining due to its compatibility with its own conception of beings. It can be said that in the western tradition, this understanding and reading of music ended with St. Boethius. His approach to music is a Pythagorian approach, which clearly shows the influence of Pythagoras on his ideas. St. Boethius' "Musica Mundana" (music of the heavens) approach is characteristically Pythagorian and it is also a reflection of the ancient musical tradition in the Christian world. St Boethius wrote his five volume work "De Instituione Musica" and there he examines the structures of music and also touches upon Pythragoras' ideas on the harmony in the universe. In addition, the first four volumes of this series were prepared based on Nichomachos' "Harmonikon Enkhiridion", while the last volume was based on Ptolemaeus" "Harmonica". Music is categorized undet "phonetic arts" by contemporary researchers, and although it seems like an independent discipline, it in fact deserves being categorized as "an expression of the cosmos" due to its significance. Along with Pythagoras and the followers of his school, many thinkers in the Islamic thought tradition have expressed ideas and wrote books about this aspect of music. The very rich connections between the sounds, harmonic utilization of the sounds and the impacts that sounds have on the human soul have channeled the thinkers of music to define music as "an expression of the cosmos". According to these thinkers, cosmos is a harmony (harmonia). And music reflects the "harmonia" between the sounds and therefore explains the cosmic harmony to a certain extent.

According to Pythagoras, who can be considered as the pioneer of this school of thought, the universe has a divine quality and thus it has to be one perfect and compact totality. Pythagoras explains this as follows: "If the 'good' is a living being with integrity, this is because the universe is restricted in itself, and consists of various pieces that have a specific order within themselves". Along with being a 'good' and a living being, the universe has a unique oneness in itself with unchangeable boundaries, and it illustrates this oneness with its ability to restructure itself. Everything in the universe has an order. All of the orbiting stars move within a perfect and eternal rotational movement. The universe, which embodies order, oneness and beauty in itself, can be defined with the word "cosmos", though it is not completely possible to express the intended meaning in most of the Western languages. Pythagoras is the first thinker to define the universe like this. And it is useful to remember that the word "cosmos" also meant order and beauty in the ancient Greek language. Along with being the first thinker to set and conceptualise the rules of music, Pythagoras also attracts attention with his cosmic comprehension and commentary on the science of music. This commentary is most probably a result of the Hermetic epistemological tradition in which he was educated; however, the fact that he explains musical harmony paral- 
lel to the cosmic harmony is worth emphasizing. These ideas and commentaries of Pythagoras have driven attention and found a resonance within the Islamic tradition of knowledge. From the 10th century on, some Islamic sources have claimed that Pythagoras was studying the seen and unseen spheres of being, he was listening to the universe, and he was even able to hear the sounds of heavens when they are orbiting in their circles.

In Pythagoras' thought, numbers have certain representations within music. Though being a pioneering philosopher in other areas of thought as well, it can be claimed that his most striking ideas are in the science of music. Pythagoras believed that intervals between two sounds, which can be defined as the perfect sound consonance, can be explained within an arithmetic system that follows the multiples of numbers 1, 2, 3 and 4 . These numbers add up to 10 , and the number 10 is accepted as the perfect number in the unusual mixture of mathematics and mysticism. This number is illustrated in geometry with "tetraktys", a geometrical shape that refers to number 10 . The octave (the 8 note structure) is illustrated with 2:1 ratio, the interval that is five degrees high or deep is illustrated with $3: 2$ ratio, and the interval between the notes $C$ and $\mathrm{F}$ is created with 4:3 ratio. Pyhtagoras has explained cosmos with harmonia, and harmonia was first of all implemented in the science of music. A group of 'Pythagorian' Muslim thinkers from the 10th century, the Ikhwan al-Safa, pointed out that the planets create certain sounds while they move; and with this thinking they get very close to the system of thought that was proposed by Pyhtagoras. These ideas of the Ikhwan can be seen as a more developed version of what Pythagoras defined as "the heavens creating a musical harmony while moving in their orbits". Pythagoras, as it has been pointed out above, narrated that he heard the harmonical sounds of the heavens, and these beautiful musical notes were imprinted on his memory, which helped him to further his interest in the musical harmony of the universe.

Ikhwan al-Safa refers to Pythagoras' claim that he heard the sounds of the planets, and with reference to some other philosophers who have developed theories in the science of music, they put forward the following ideas: "Children imitate the behaviours of their parents. Students imitate those of their teachers. A public imitates their rulers. Those who have the faculty to think tend to aspire to the perfect state of angels. Like this, in the created sphere, there are orderly movements with harmonic tunes. These orderly and nearly-perfect movements also aspire to a higher level of harmonic tunes in the heavens. As it has been pointed out in the philosophical discussions, this is a reflection of man's aspiration to the creator within the limits of his power." Pythagoras, with his pure intellect of heart, heard the tunes of the movements of heavens; and with the magnanimity bestowed upon his faculties, revealed his unique musical methods and tunes. In the Islamic tradition, Ikhwan al-Safa is known for embracing the system of thought of Pythagoras. This group of thinkers have written an encyclopedic resource consisting of 52 separate letters (risalat), and in these letters they developed their systems of music based on Pythagoras' conceptualisation of harmony and music. Just like Pythagoras, Ikhwan al-Safa refers to the existence of certain harmony (harmonia) within the universe. After talking about the harmony among all of the created beings in the universe and their degrees of harmony, Ikhwan al-Safa suggests that a similar kind of harmony is also present amongst the planets, and that these planets create very harmonic tunes in their movements. Besides in this system of thought, these tunes are compared and at the same time likened to the tunes created by the instrument oud. 
I brought examples from Pythagoras and later Pythagorean thinkers to the explanation of music as a mirror of the cosmos ever since Hermes in ancient civilizations in the first section of my paper explaining the expression of music with cosmic symbols. The first section also includes the reflections of this cosmic approach to music in the tasawwuf literature and Turkish classical music. In the second section, I treat the relationship between the harmony in the cosmos and the harmony in music using the case of Pythagoras' understanding of the cosmos. This section analyzes the relationship between the movement of celestial spheres and music as expounded by Pythagoras -the theory of the Harmony of Spheres-and the impact of this understanding on the Islamic civilization, where it was introduced by Ikhwān Al-Ṣafā. In the third section, I tried to trace the connection of Ottoman and Islamic musical thought to the musical thinking of the civilizations of antiquity by focusing on the origin and the impact of Ikhwān Al-Ṣafā. This paper outlines the cosmic understanding of music from antiquity to the Islamic period by focusing on how various ancient and Muslim thinkers understood the relationship between music and the universe.

\section{Keywords}

cosmos, harmonia, pythagoras, ikhwan al-safa, planets 